\title{
Challenges posed by the global crisis in the health workforce
}

\author{
No workforce, no health
}

\author{
James Buchan professor $^{1}$, Jim Campbell director ${ }^{2}$ \\ ${ }^{1}$ Queen Margaret University, Edinburgh EH27 6UU, UK; ${ }^{2}$ Instituto de Cooperación Social Integrare, Barcelona, Spain
}

In May 2013, the World Health Assembly recognised that renewed attention to the "health workforce crisis" is central to achieving quality healthcare through universal health coverage. ${ }^{12}$ Next month, the Third Global Forum on Human Resources for Health will convene to agree on what can and should be done across all countries to solve the crisis. ${ }^{3}$ Often oversimplified as a numerical shortage of healthcare workers, the crisis also has management, quality, location, and performance dimensions. These problems have often been recognised (hence the much used phrase "right staff, right place, right time, right skills") but rarely dealt with effectively.

Although the impact of the health workforce crisis is most evident in emerging economies, advanced economies have not escaped and will have a major role in local, national, regional, and global solutions to the multidimensional challenges. This includes responding to drivers of change, such as financial austerity, and the "double whammy" of an ageing population and ageing health workforce, which present both an opportunity for transformative thinking and a threat to the status quo.

In advanced economies, the starting point for any analysis of the health workforce crisis is the impact of another crisis- the global financial meltdown in 2008 and its aftermath on healthcare spending and labour markets, notably in Europe. Healthcare spending grew on average by close to $5 \%$ each year from 2000 to 2009 in OECD (Organisation for Economic Co-operation and Development) countries, but stagnation followed the financial crisis, mainly because of the "collapse" in the growth of government expenditure on health. For example, in Greece, overall healthcare spending dropped by $11 \%$ in both 2010 and 2011; in Portugal, public spending dropped by $8 \%$ in 2011. In only two OECD countries-Israel and Japan-has healthcare spending increased since $2009 .{ }^{4}$

Against this backdrop, ageing populations (affected by comorbidities and long term conditions) are generating more demand for healthcare, while the healthcare workers looking after them are also ageing. Concerns about the future supply of health professionals are growing. In 2009, about $30 \%$ of all doctors in European Union countries were aged over 55 years. ${ }^{5}$ The average age of nurses in advanced economies is in the $40 \mathrm{~s} .{ }^{6}$
Recent projections in a range of OECD countries point to possible reductions in the size of the nursing workforce, mainly because of ageing and increased retirement. ${ }^{5}$ Although based on rudimentary analysis, the European Commission estimates a potential shortfall of one million professional healthcare workers across EU countries by $2020 .^{5}$

To have any hope of solving this crisis and creating a healthcare workforce that is fit for purpose in the 21st century, a clearer definition of the problem is needed. It is not only the relatively simple problem of workforce deficits-even if sufficient funding were available, the solution is not just to "train more."

Put simply, there are four key problems regarding human resources for health that advanced economies need to deal with. Firstly, many countries have a sufficient overall number of doctors, but some are in the wrong place or working in the "wrong" specialty to maximise access to care. Secondly, the likelihood of a fall in nursing and midwifery workforce numbers must be dealt with urgently. Thirdly, more policy and funding effort is needed to improve retention of workers, reduce costly attrition and out-migration, and make the workforce stable enough to ensure that investment in new skills is financially prudent. These efforts are needed to meet changing patterns of healthcare demand, most notably in managing chronic disease and delivering primary care. Finally, improvements in workforce performance will have to be achieved through better use of current skills, improved skill mix, new roles, effective incentives, supportive working conditions, integration, and teamwork. This all speaks to the need for more responsive workforce planning, better alignment between education providers and the needs of employers, improved management, and a sustained policy focus.

Some efforts to meet these challenges are already under way. The OECD has reviewed the strengths and weaknesses of different national approaches to the planning of healthcare workforces, ${ }^{7}$ and it is currently completing a review of the effectiveness of different policies aimed at improving the distribution of doctors. The EU has launched a "joint action" on the healthcare workforce, which includes an emphasis on improved workforce planning, an assessment of retention 
policies, and skills developments. ${ }^{6}$ In September 2013, representatives of high income countries met at a "pre-forum" consultation in Norway to examine recent policy and planning initiatives regarding the healthcare workforce. They also discussed where they can make "commitments" to support improvements in human resources for health, both domestically and in emerging economies. ${ }^{8}$

Although many of the multidimensional workforce challenges will have to be met mainly at national level, there is also a global imperative, implicit in the right to health, for shared responsibility and a collective response. Both the domestic solutions in advanced economies and international solidarity with emerging economies are on the agenda at the global forum. The aspiration for universal health coverage will not be achieved without global and shared commitment to a transformative health workforce agenda. That agenda must take account of the universal truth in all countries and in all health systems: no health without a workforce.

Competing interests: We have read and understood the BMJ Group policy on declaration of interests and declare the following interests: None.
Provenance and peer review: Commissioned; not externally peer reviewed.

1 WHO. Universal health coverage: report by the secretariat (EB132/22). 2013. http://apps who.int/gb/ebwha/pdf_files/EB132/B132_22-en.pdf.

2 WHO. The health workforce: advances in responding to shortages and migration, and in preparing for emerging needs: report by the secretariat (EB132/23). 2012. http://apps. who.int/gb/ebwha/pdf_files/EB132/B132_23-en.pdf.

3 Global Health Workforce Alliance. Third Global Forum on Human Resources for Health Rising to the grand challenge of human resources for health. 10-13 November, 2013. Recife, Brazil. www.who.int/workforcealliance/forum/2013/en/

4 Organisation for Economic Co-operation and Development. Health spending continues to stagnate, says OECD. 2013. www.oecd.org/health/health-spending-continues-tostagnate-says-oecd.htm.

5 European Commission. Commission staff working document on an action plan for the EU health workforce. EC, 2012

6 International Council of Nurses. International Council of Nurses Workforce Forum. Nursing workforce profile database summary. 2011. www.icn.ch/images/stories/documents/pillars/ sew/DATASHEET_SUMMARY_NURSING_PROFILE_2011.pdf.

7 Ono T, Lafortune G, Schoenstein M. Health workforce planning in OECD countries: a review of 26 projection models from 18 countries. OECD Health Working Papers, No 62, OECD Publishing. 2013. http://dx.doi.org/10.1787/5k44t787zcwb-en

8 Global Health Workforce Alliance. Consultation on human resources for health for high-income countries. 2013. www.who.int/workforcealliance/media/news/2013/ osloconsultation/en/index.html.

Cite this as: BMJ 2013;347:f6201

(๑) BMJ Publishing Group Ltd 2013 